University of Nebraska - Lincoln DigitalCommons@University of Nebraska - Lincoln

USDA National Wildlife Research Center - Staff U.S. Department of Agriculture: Animal and Plant Publications

Health Inspection Service

2018

Perspectives on Existing and Potential New Alternatives to Anticoagulant Rodenticides and the Implications for Integrated Pest Management

Gary W. Witmer

USDA National Wildlife Research Center, gary.w.witmer@usda.gov

Follow this and additional works at: https://digitalcommons.unl.edu/icwdm_usdanwrc

Part of the Life Sciences Commons

Witmer, Gary W., "Perspectives on Existing and Potential New Alternatives to Anticoagulant Rodenticides and the Implications for Integrated Pest Management" (2018). USDA National Wildlife Research Center - Staff Publications. 2095.

https://digitalcommons.unl.edu/icwdm_usdanwrc/2095

This Article is brought to you for free and open access by the U.S. Department of Agriculture: Animal and Plant Health Inspection Service at DigitalCommons@University of Nebraska - Lincoln. It has been accepted for inclusion in USDA National Wildlife Research Center - Staff Publications by an authorized administrator of DigitalCommons@University of Nebraska - Lincoln. 


\title{
Chapter 13 \\ Perspectives on Existing and Potential New Alternatives to Anticoagulant Rodenticides and the Implications for Integrated Pest Management
}

\author{
Gary W. Witmer
}

\section{Introduction to Rodents and the Damage they Cause}

Comprising over 1400 species worldwide, rodents are the largest taxonomic group of mammals (Nowak 1999). Rodent use of habitats is extensive and varied. Most rodent species are relatively small, secretive, prolific, adaptable, and have continuously growing incisors which require constant eroding by gnawing. Rodents are known for their high reproductive potential; however, there is much variability between species as to the age at first reproduction, size of litters, and the number of litters per year. All rodent species have ecological, scientific, social, and/or economic values. They recycle nutrients, aerate soils, distribute seeds and spores, and affect plant succession. Some provide meat and furs for people. Several species are used in large numbers in medical research. Additionally, they provide an important prey base for many species of predatory animals.

Relatively few (perhaps 5\%) rodent species around the world are serious pests. Examples of genera and species of rodents considered to be serious pests around the world were provided by Prakash (1988) and Witmer and Singleton (2012). Numerous economic and health problems can result from rodent interactions with humans. Damage can occur to agricultural crops (both in the field and to stored foods), forests and orchards, rangelands, property (structures, cables), natural resources (both faunal and floral), and disease hazards may be posed (Marsh 1988; Witmer and Singleton 2012). Singleton et al. (2003) estimated that in Asia alone, the amount of grain eaten by rodents would provide enough food to feed 200 million people for a year. When a damage situation occurs, it is very important to determine the species causing the damage, the extent of the damage, and the abiotic-biotic-cultural factors

\author{
G.W. Witmer $(\bowtie)$ \\ USDA National Wildlife Research Center, Fort Collins, CO, USA \\ e-mail: Gary.W.Witmer@aphis.usda.gov
}


involved before rodent population and damage management strategies are implemented (Singleton et al. 1999; Witmer and Singleton 2012). Damage can be particularly severe when rodent population outbreaks occur (Singleton et al. 2010).

The commensal rodents include the Norway rat (Rattus norvegicus), the ship or black rat (R. rattus), the Polynesian rat or kiore (R. exulans), and the house mouse (Mus musculus and M. domesticus). These species live in close proximity to humans, exploiting the favorable conditions that are created for them. As a result, they have spread throughout most of the world and cause significant losses of stored food stuffs. Additionally, they have also been especially damaging to insular ecosystems when introduced-generally accidently or inadvertently - to islands (Angel et al. 2009; Witmer and Pitt 2012).

Despite the many methods available to reduce rodent populations or the damage they cause, rodenticides have been heavily relied upon for many decades (e.g., Witmer and Eisemann 2007; Witmer et al. 2007b). However, there has been a growing concern about the hazards posed by rodenticides. In particular, there is concern about the toxicity and persistence in tissues of anticoagulant rodenticides (e.g., Eisemann et al. 2010; Nogeire et al. 2015; Pelz 2007; Pitt et al. 2015; Proulx 2014; Rattner et al. 2012; 2014a, b). This concern is documented in many of the other chapters of this book. The objective of this chapter is to describe the alternative methods to anticoagulant rodenticides for the control of rodent populations and damage. Both lethal and non-lethal methods are described and we also discuss the value of an integrated pest management (IPM) approach or an ecologically-based rodent management approach. While the emphasis of this chapter is the United States (US), it includes examples and citations from other countries.

\section{Developing an Integrated, Robust Approach to Rodent Management}

While rodenticides have been heavily relied upon to control rodent populations around the world, there are many other methods available to help reduce rodent damage and to reduce their populations (Table 13.1; Buckle and Smith 2015; Caughley et al. 1998; Hygnstrom et al. 1994; Witmer and Singleton 2012). The long-term results are generally best if a variety of methods are employed, however, many practitioners prefer to use the one method they have found to be effective and cost-efficient (Baldwin et al. 2014). As with the control of weeds and damaging insects, the development and implementation of an integrated pest management (IPM) program provides the best guarantee of a sustainable control program (Witmer 2007). Reliance on a single method may lead to declining effectiveness over time as has been the case with genetic and behavioral resistance to anticoagulants in some rodent populations. This has been seen in some cases with other single method approaches, such as trap shyness or habituation to frightening devices and repellents. To help prevent these situations from developing, rodent researchers 
Table 13.1. Methods and techniques for rodent control that have been suggested, tested, or used for various rodent problem situations (from Witmer and Singleton 2012)

\begin{tabular}{l|l|l|l}
\hline Physical & Chemical & Biological & Other \\
\hline $\begin{array}{l}\text { Rodent proof } \\
\text { construction }\end{array}$ & Baits/baiting systems & $\begin{array}{l}\text { Virally-vectored } \\
\text { fertility control }\end{array}$ & Bounties \\
\hline Passive barriers & Glueboards & Immunogens & Insurance \\
\hline Electric barriers & Poison sprays & Habitat modification & Harvest \\
\hline Drift fences & Poison moats & Cultural practices & \\
\hline Trapping & Tracking powder & Crop timing & Compensation \\
\hline Flooding burrows & Tracking greases, gel & $\begin{array}{l}\text { Crop diversification, } \\
\text { and species selection }\end{array}$ & Appeasement \\
\hline Drives & Repellents & Buffer crops & \\
\hline Hunting & Attractants & Parasites & \\
\hline Clubbing & Aversive agents & Diseases & \\
\hline Frightening devices & Plant systematics & Predators & \\
\hline Flame throwers & Sterilants & Ultrasonics & \\
\hline Burrow destruction & Fumigation & Biosonics & \\
\hline Habitat destruction & Psychotropic drugs & Resistant plants & \\
\hline Harborage removal & Herbicides & Lethal genes & \\
\hline $\begin{array}{l}\text { Supplemental } \\
\text { feeding }\end{array}$ & $\begin{array}{l}\text { Poisons mixed with } \\
\text { vehicle oil applied to } \\
\text { flooded rice }\end{array}$ & Endophytic grasses & \\
\hline Digging & & Unpalatable plants & \\
\hline $\begin{array}{l}\text { Dogs together with } \\
\text { flooding or digging }\end{array}$ & & & \\
\hline & & & \\
\hline
\end{tabular}

have proposed the development and implementation of ecologically-based rodent management (EBRM; Singleton et al. 1999). An important component of this approach is the periodic monitoring of rodent populations so that appropriate action(s) can be taken before heavy damage is unavoidable (Witmer 2005). Another important aspect of EBRM is the building of community cooperation; several examples of this can be found in Singleton et al. 2003. Rodents do not recognize legal or political boundaries, so that even a well-planned rodent control program may be inefficient and doomed to poor success if surrounding landowners are not also participating in effective rodent control. This results from the high reproductive potential and effective dispersal mechanisms of many rodent species.

It should be noted that the methods listed in Table 13.1 vary substantially in their effectiveness, durability, and cost. It is important for practitioners to become experienced in the proper use of the methods and to be using the methods properly. There are some manuals and brochures/booklets available to help persons gain that insight (e.g., Buckle and Smith 2015; Hygnstrom et al. 1994; county and university cooperative extension materials). 


\section{Regulations, Restrictions, and International Standards}

The use of certain tools and methods discussed in this chapter (and in particular, rodenticides and traps) are generally regulated by governmental agencies within a country or political boundary. These agencies assess control methods and decide which can be used, and the "when, where, and how" of their use. Additionally, the regulations and restrictions vary widely across political jurisdictions be they federal, state, provincial, county, or municipal. They also vary over time. Hence, it is important for a potential user to check with the appropriate agency(s) as to what their current options are for rodent population or damage control.

Additionally, there have been increasing concerns about the potential non-target hazards and humaneness of rodenticides and traps. Hence, regulations and restrictions have increased for many tools. For example, the U.S. Environmental Protection Agency has made more rodenticides "Restricted Use Pesticides" so that they can only be applied by certified pesticide applicators; an example of this is zinc phosphide use in the U.S. Furthermore, in the U.S., the International Association of Fish and Wildlife Agencies (2006) determined "Best Management Practices" for furbearer trapping; these apply to some rodent species trapped for their fur: nutria (Myocastor coypus), muskrats (Ondatra zibethicus), and beaver (Castor canadensis). Additionally, the International Organization for Standardization (IOS) has recommended methods for testing the humaneness of kill traps (ISO 1999a) and for restraining traps (IOS 1999b). However, there appears to be relatively little agreement on all these matters between countries and even between jurisdictions within a country. It has been proposed that new animal welfare standards need to be established (Lossa et al. 2007).

\section{Acute and sub-Acute Oral Toxicants}

Aside from the anticoagulant rodenticides (ARs), there is a number of alternative toxicants that can be used for rodent control. These include the acute and sub-acute oral toxicants and fumigants. A brief discuss these materials and their uses as well as some advantages and disadvantages follow.

The acute and sub-acute oral rodenticides are so named because these chemicals cause adverse effects in organisms much more quickly than the ARs. Depending on the chemical, this is through relatively rapid physiological disruption or organ failure. These materials include cholecalciferol (vitamin $\mathrm{D}_{3}$ ), strychnine, zinc phosphide, bromethalin, and alpha-chloralose. In some countries, compound 1080 (monosodium fluoroacetate) is used as a vertebrate toxicant; however, it is no longer legal in some countries, including the US. The modes of action of these materials have been described previously (Buckle and Eason 2015; Eason et al. 2010; Timm 1994). These materials generally contain somewhat higher concentrations $(0.01-$ $2 \%)$ of the active ingredient than do the AR baits (0.025-0.005\%). Like the ARs, they come in a variety of formulations for oral consumption, including pellets, 
coated grain, paste baits, and sachets. Additionally, zinc phosphide also is available in a tracking powder (placed along runways or in burrows whereby the rodents walk through it and then consume the toxic powder when they groom themselves). Depending on the label instructions, these materials (like the ARs) can be broadcast, placed in burrows or bait stations, or placed along runways.

Because the acute rodenticides are highly toxic to most bird and mammal species, they pose a significant hazard to most species through direct consumption, including people (especially children), livestock, and pets. As such, great care must be taken to avoid exposure to non-target animals. This is especially important because there are no antidotes to these toxicants. On the other hand and unlike the ARs, these materials are relatively rapidly metabolized and eliminated (i.e., dissipated as gas; zinc phosphide as phosphine gas) so there is little hazard from the secondary consumption of poisoned rodents. Some consider the acute rodenticides to be more humane than the ARs because death occurs relatively rapidly after consumption of a lethal dose. This is in contrast to the slow death from AR consumption whereby the rodent slowly dies from internal--and sometimes external-hemorrhaging. On the other hand, some of the acute rodenticides result in gasping and convulsions shortly before death, which is considered by some to be signs of an inhumane death.

A disadvantage of the relatively quick onset of signs of intoxication with acute rodenticides is that the animal may associate the consumption of the toxic bait with the onset of adverse effects. As a result of this, rodents consuming a sub-lethal dose may become "bait shy" whereby they will not consume the toxic bait in the future. Also, as with the ARs, some populations of rodents have developed a resistance to the toxic effects of some acute rodenticides (e.g., strychnine).

\subsection{Alpha-Chloralose}

Alpha-chloralose is an organic compound (narcotic) evoking a rapid onset of intoxication. It was developed as a house mouse rodenticide in Europe where it is registered, manufactured and sold for use in mouse control. The products generally contain $4 \%$ active ingredient. This agent slows down several metabolic functions resulting hypothermia and death. It is most effective with smaller rodents, such as mice, because of their high surface area to body volume ratio. The $\mathrm{LD}_{50}$ is about 300-400 mg/kg (Buckle and Eason 2015; Timm 1994).

\subsection{Bromethalin}

Bromethalin is a benzenamine compound. It was developed in the United States where it is registered and often used for rodents that have developed a resistance to anticoagulants. The products generally contain $0.005 \%$ or $0.01 \%$ active ingredient. 
It causes the uncoupling of oxidative phosphorylation in cells of the central nervous system which eventually leads to a decrease in nerve impulse conduction, paralysis, and death. The $\mathrm{LD}_{50}$ is about 2-6 mg/kg (Buckle and Eason 2015; Timm 1994).

\subsection{Cholecalciferol}

Cholecalciferol (vitamin $\mathrm{D}_{3}$ ) is an organic compound causing the mobilization of calcium from bones, resulting in hypercalcemia and cardiac abnormalities, and death results from hypercalcemia in various organs. It was developed and registered in the United States and Europe, but the European registration was later dropped in preference to the second generation anticoagulants. The products generally contain $0.075 \%$ active ingredient. The $\mathrm{LD}_{50}$ is about $30-40 \mathrm{mg} / \mathrm{kg}$ (Buckle and Eason 2015; Timm 1994).

\subsection{Red Squill}

Red squill (scilliroside) is a stabilized and micronized glucoside. It causes a digitalislike action and results in heart paralysis. It was first isolated from an aquatic plant (Urginea maritima) in the lily family. It was first developed in Switzerland, but was later registered and used in the United States and sold to other countries as well. The product is not readily available anymore and its used has dropped substantially in preference to the second generation anticoagulants. The products generally contain $0.05 \%$ active ingredient. The $\mathrm{LD}_{50}$ is about $50-200 \mathrm{mg} / \mathrm{kg}$ (Buckle and Eason 2015; Timm 1994).

\subsection{Sodium Fluoroacetate (1080)}

Sodium fluoroacetate (also known as compound 1080) was first isolated from a poisonous African plant (Dichapetalum toxicarium) by researchers in Europe who surmised that it might be useful as a vertebrate toxicant. The drug is rapidly absorbed in the gastrointestinal tract and blocks the tricarboxylic acid cycle which results in a build-up of citric acid and the blockage of glucose metabolism, eventually leading to convulsions and either circulatory or respiratory failure. It is toxic to a wide array of vertebrates and has been registered and used as a vertebrate toxicant in many countries, especially Australia and New Zealand. However, it has very limited current use in the United States where it is only used in livestock protection collars. Products generally contain $0.08 \%$ or $0.5 \%$ active ingredient. The $\mathrm{LD}_{50}$ is about 0.1-6 mg/kg (Buckle and Eason 2015; Timm 1994). 


\subsection{Strychnine}

Strychnine is a botanical compound first isolated from the poisonous seeds of a tree species (Strychnos spp.). It is an alkaloid antagonizing glycine and acetylcholine receptors, resulting in muscle twitching and restlessness, followed by convulsive seizures and violent spasms and death. It was developed as a rodenticide in Europe and its use increased when it could be synthesized commercially rather than extracted from seeds. Because of its high toxicity to most mammalian species, its use is limited in many countries. In the United States, there are no above ground uses allowed and it is only registered for use in rodent burrow systems, and in particular, in pocket gopher burrows. It is no longer registered for use in Europe. It is still used in Australia to help control house mouse irruptions ("plagues"). Pelleted baits generally contain $2 \%$ active ingredient, but it is also used to coat vegetables, grains and fruits at $0.5 \%$ active ingredient. The $\mathrm{LD}_{50}$ is about $1.5-8 \mathrm{mg} / \mathrm{kg}$ (Buckle and Eason 2015; Timm 1994).

\subsection{Zinc Phosphide}

Zinc phosphide is an inorganic compound that is converted into phosphine which inhibits cytochrome oxidase. It was developed and first used as a rodenticide in Europe. It is perhaps the most widely used rodenticide in the world. Like strychnine, it is heavily used in Australia to control house mouse plagues. It is produced and sold in many forms: pellets, coated grains, tracking powder, and as a concentrate used to coat vegetables and fruits. Most oral baits contain 2\% active ingredient. When consumed, the bait releases phosphine gas upon exposure to the moisture and acid in the stomach. Phosphine gas is highly toxic. It quickly enters the blood stream and causes heart failure and damage to various organs. Signs of intoxication include convulsions, paralysis, coma and death. The onset of intoxication is so rapid that if the animal has not consumed a lethal dose, it will recover and then will be "baitshy" and will no longer consume the bait. Hence, it is often recommended that the area be pre-baited with uncoated grain before the coated grain is applied. The $\mathrm{LD}_{50}$ is about 20-40 mg/kg (Buckle and Eason 2015; Timm 1994).

\subsection{Research on New Active Ingredient Toxicants and Combination Toxicants}

Because of the increased restrictions on rodenticide use, the loss of some products from the commercial market, the many concerns about rodenticide humaneness and non-target hazards, and the fact that some are no longer effective against the targeted rodent species, research is expanding on potential new rodenticides. This 
situation applies to both the anticoagulant and acute rodenticides. Researchers are investigating new active ingredients as well as rodenticides containing two-active ingredients (i.e., an anticoagulant and an acute toxicant in one bait, but at lower concentrations than in single active ingredient rodenticides). A new active ingredient, sodium nitrite, is being evaluated as a rodenticide and as a feral pig toxicant (Blackie et al. 2014; Eason et al. 2010). However, preliminary studies suggest it may be much more effective with feral pigs than with rodents (Campbell et al. 2015; Witmer et al. 2013). Some researchers are re-visiting formerly registered active ingredients such as norbormide (Campbell et al. 2015). Some of the research efforts with potential new rodenticides have been reported by Baldwin et al. $(2016,2017)$, Blackie et al. (2014), Campbell et al. (2015), Eason et al. (2010), Morgan et al. (2013), Witmer and Moulton (2014), and Witmer et al. (2014a). Another recent research area that is showing good promise is the development and testing of longterm, re-setting toxin delivery systems (Blackie et al. 2014; Murphy et al. 2014; Witmer and Moulton 2016).

\section{Fumigants}

Fumigants are materials that when exposed to water, or are ignited, produce toxic gases. As such, some chemicals are used to kill rodents by fumigating (i.e., filling) the structure they are living in or their burrow system with poisonous gas. The mode of action of these materials is to cause death by asphyxiation or other form of respiratory failure. Fumigants include aluminum phosphide, magnesium phosphide, acrolein, the carbon/sodium nitrate contained in an ignitable cartridge, and propane gas injected into the burrow and then ignited. There is a high concentration of the active ingredient in these toxicants (generally, $\geq 56 \%$ ). Once placed in the burrow, all burrow openings must be sealed to achieve a high degree of effectiveness. Fumigation is usually highly effective especially when soil moisture levels are fairly high; if the soils are dry and cracked, the gas may dissipate too rapidly to have its lethal effect. The methods are used in agricultural settings and around structures. However, use of the materials in structures is highly regulated or restricted because of the risk to humans, livestock, and pets. The gases produced by the fumigants rapidly dissipate so that there is generally only a short-term potentially hazardous situation. However, presumably all vertebrates in the treated burrow system would be at risk of death as well as most invertebrates present. The use of fumigants has been described by Hygnstrom et al. (1994).

\section{Traps}

A wide array of traps have been developed and used to manage rodents and many types are commercially available (Hygnstrom et al. 1994; Proulx 1999). Trap types are subdivided into live traps and kill traps. With live traps, the rodent becomes 
contained in a box or cage trap after tripping a treadle. Another type of live trap is the leg-hold trap which, when tripped by the rodents paw, springs the jaws of the trap to close tightly around the leg and hold the animal until the trapper or researcher arrives. Leg-hold traps are generally only used for larger rodent species such as nutria (Myocastor coypus), muskrats (Ondatra zibethicus), and beaver (Castor canadensis). Live traps and leg-hold traps generally can be purchased through various commercial outlets. Animals captured in live traps can be relocated (where regulations allow) to other locations or euthanized. An advantage of live traps is that non-target animals captured can often be released unharmed.

Kill traps cause the rapid death of the rodent by body constriction when the rodent trips the trap's trigger mechanism. The most common type of rodent kill trap is the snap trap. Another type of kill trap is the Conibear trap used for larger rodent species. Kill traps can generally be purchased through a variety of commercial outlets. Hygnstrom et al. (1994) provided good illustrations of various types of traps and directions for their proper and effective use. Effective trapping requires skill and practice. Using the proper type of trap for the situation, proper placement, and appropriate bait or lure is very important to achieve a high level of trap success (i.e., a high capture rate). Considerable effort has gone into identifying effective lures and baits for traps (e.g., Jackson et al. 2015; Jojola et al. 2009; Witmer et al. 2010, 2014b). A disadvantage of kill traps is they can injure or kill non-target animals, including birds. Various types of traps are also used to monitor rodent populations. Rodent population monitoring is essential so that necessary management action can be taken before populations get very large at which point extensive damage to resources cannot be avoided (Witmer 2005). Additionally, using traps over large areas is very labor intensive. However, once the rodents have been removed from a large area, often a boundary/perimeter trapping strategy can be employed to greatly slow reinvasion (Proulx 1997).

Self-resetting, multiple kill traps have been developed in New Zealand for control of invasive rats and other invasive species such as stoats (Mustela ermine) and brush-tailed possums (Trichosurus Vulpecula) (Peters et al. 2014). This was, in part, to reduce the high labor costs of running trap lines which requires frequent checking and resetting. However, Warburton and Gormley (2015) determined which type of tap was more efficient: at low densities, larger numbers of single capture traps were more efficient, whereas at higher densities, fewer multiple capture traps was more efficient. Research is also underway to improve the species-specificity of selfresetting, multiple kill traps (e.g., Blackie et al. 2014; Campbell et al. 2015).

Another type of trap is the glueboard. Glueboards are a non-toxic device used to catch and hold mice, and to a lesser extent, rats. The advantages of glueboards are that they are non-toxic, non-contaminating, hold the carcass in one place, have a high capture rate for animals that encounter them, require no license for their use, and are inexpensive (Cowan and Brown 2015). On the other hand, the sticky substance in the flat trays holds the rodent until it dies, presumably from dehydration and/or starvation. Because of that slow---and presumably painful form of death--glueboards are considered inhumane by many. For that reason, some European countries have banned the use of glueboards. More recently, New Zealand banned the use of glueboards, although many exemptions are issued (Cowan and Brown 
2015). Corrigan (1998) reported that glueboards weren't particularly effective with house mice. Additionally, glueboards are non-selective so that non-target animals can be captured (e.g., bats, birds, skinks). Live traps, kill traps, and rodenticides are considered the best alternatives to glueboards where they can be effectively and safely used (Cowan and Brown 2015; Corrigan 1998, 2001).

\section{Barriers and Exclusion}

An alternative approach to reduce or eliminate rodent damage is to exclude them from high value areas. This is an attractive option in some situations because it is a nonlethal approach and could, potentially, solve the problem on a permanent basis. Exclusion devices include physical barriers (e.g., fencing, sheet metal, or electric wires), frightening devices, ultrasonic or vibrating devices, or chemical repellents (Buckle and Smith 2015; Hygnstrom et al. 1994). Unfortunately, it is very difficult to keep rodents out of any area that they attempt to enter. They can usually get over, around, under, or through any kind of barrier put in their way. Their small size, flexibility, agility, gnawing capability, along with their climbing and digging abilities make them a formidable adversary. They also habituate rather quickly to noxious odors, sounds, or lights (e.g., Timm 2003). There are detailed guides available on how to rodent-proof buildings, but success is achieved only with much effort, expense, diligence, and maintenance (Corrigan 2001; Baker et al. 1994). In open settings such as croplands or orchards, the task is much more difficult and the chance of success is small. Although research in this area continues, there are few successes to report at this time (Pelz 2003; Witmer et al. 2007c, 2008b).

Short, low voltage, electric fences have been used with some success to exclude rodents from areas, but there were a number of concerns such as non-target hazards and excessive maintenance to keep the fences operating properly (Ahmed and Fiedler 2002; Buckle and Smith 2015; Shumake et al. 1979). In Asia, small landholder farmers cannot afford voltage regulators and instead some farmers directly run 220 volt power lines around their fields. This has led to deadly results not only for the rats but also for buffalo, goats and humans.

Physical barriers around individual tree seedlings have shown some success, but, again, there were concerns about cost, maintenance, and adverse effects on seedling growth (Marsh et al. 1990).

\section{Repellents}

A number of rodent repellents have been registered by the USEPA for use in the United States, but their effectiveness is generally considered to be low. Nonetheless, considerable research effort has gone into-and continues-to identify effective repellents for rodents. Predator odors have shown some effectiveness in some trials 
for repelling rodents and other herbivores from areas or individual plants (Mason 1998; Sullivan et al. 1988), but little effectiveness in other trials (e.g., Salatti et al. 1995). The sulfurous odors in predator urine, feces, glandular excretions, blood/ bone meal, and putrescent eggs derived from the break-down of animal protein, all potentially serve as a cue to herbivores that a predator may be in the area and pose a threat to the herbivore (i.e., the potential prey; Mason 1998). Another repellent that has shown some promise is capsaicin (a natural ingredient found in chili peppers), but a fairly high concentration $(\geq 2 \%)$ of this expensive material is usually needed for a reasonable level of effectiveness (Mason 1998). The product usually comes as a liquid concentrate that contains a solvent and an adhesive agent so that it sticks to the material to be protected when it is sprayed or brushed on. Recent studies have shown some other plant secondary metabolites to be effective as rodent repellents (Hansen et al. 2015; Hansen et al. 2016). While these and other compounds have shown promise as rodent repellents in cage and pen trails (Ngowo et al. 2003; Oguge et al. 1997; Pelz 2003; Witmer et al. 2001), yet to be shown is broadscale field efficacy of rodent repellents. Some of the issues are that animals may acclimate/habituate to the materials and the effectiveness depends on how hungry the animals are and whether or not palatable alternative foods are available. In another, related research area, efforts are underway to incorporate bird repellents into rodenticides to reduce the risk of harming non-target animals (Cowan et al. 2015; Werner et al. 2011).

\section{Habitat Management}

Because rodent food and cover (i.e., vegetation, debris piles, food waste) can be greatly influenced by human activities, strategies have been developed to reduce populations and damage by manipulating vegetation and other features in the human-altered landscape. Many of these manipulations are not done just to reduce rodent habitat (which may be an incidental benefit) but for other reasons such as to reduce vegetative competition with crops or trees, to reduce soil pathogens, or to prepare sites for planting. Burning, plowing, disking, herbicide application all reduce vegetative cover, at least for the short term, and usually greatly reduce rodent populations (Massawe et al. 2003; Witmer et al. 2007c). Plowing and disking have the additional advantage of disrupting the burrows of rodents (Salmon et al. 1987). However, in some cases, disking and soil compaction have not reduced rodent numbers (Witmer and Borrowman 2012). These methods have been used extensively in reforestation, orchards, and traditional agriculture. Understandably, farms that have implemented no-till agricultural practices to reduce erosion, water loss and improve soil fertility have continued to suffer from high populations of rodents because the soil is not disturbed to an adequate depth and plant stubble (residues) are left on the surface (Witmer and VerCauteren 2001; Witmer et al. 2007c). Problems from rodents are compounded when grassy refugia are left along the periphery of crop fields that rodents can make use of when crop fields are rather bare (Brown et al. 
2004). Additionally, a winter food supply for rodents is created by the spilled grains of crops such as wheat, barley, and legumes (Witmer et al. 2007c, Witmer 2011).

There has been some success in the use of lure crops or supplemental feeding to reduce damage by rodents or other vertebrates. Cracked corn or soybeans have been broadcast as lure crops (after drill-seeding in no-till cropland) to divert voles and other rodents from feeding on newly emerged crop seedlings or digging up and feeding on planted seeds (Witmer and VerCauteren 2001). Sunflower seeds were broadcast on forest stands subject to tree squirrel damage with a subsequent reduction in tree damage (Sullivan and Klenner 1993). A trap-barrier-system (TBS) was developed that uses some early planted crop fields to lure rodents into them (Singleton et al. 1998; reviewed in Singleton et al. 1999, 2003). The lure fields are surrounded by a rodent barrier, but there are regularly spaced openings into multiplecapture rodent traps. The rodents in the traps are collected and killed daily. In some developing countries, the rodent carcasses are used as a source of high-protein food for humans and animals (Jacob et al. 2002; Jahn et al. 1999; Singleton et al. 2007). This TBS method has reduced rodent invasion into the surrounding crop fields that are planted 2-3 weeks later. Aside from this clever use of multiple capture live traps, trapping for rodents is rarely effective or efficient in reducing populations over large acreages. One exception was coordinated community actions at a village level (100-200 ha) in intensively farmed rice fields in Southeast Asia where the average farm size was generally less than 1.5 ha (Singleton et al. 2005).

Another approach to vegetation manipulation still under investigation is the use of endophytic grasses. These are grass varieties that contain an alkaloid-producing fungus that can improve the hardiness of the grass and reduce herbivory. Some preliminary studies suggest that endophytic grass fields support lower rodent densities (Fortier et al. 2000; Pelton et al. 1991). These grasses could potentially be used in a variety of settings, but might be very valuable around cropfields and orchards where grassy areas have served as a traditional refugia for rodents and, hence, a source of dispersing individuals. They may also reduce rodent populations in the large grassy areas at airports. The mixture of grass and herbaceous species provides food and cover for rodents which, in turn, attracts raptors; these large birds cause a birdaircraft strike hazard at many airports (Witmer 2011). Other species of unpalatable plants may offer a similar approach to lowering the rodent carrying capacity of a site (Giusti et al. 1996; Witmer and Fantinato 2003).

Rodents compete for food with a variety of herbivores, including other wildlife and livestock. There is some evidence that rodent populations can be reduced by intensive cattle or sheep grazing (Hunter 1991; Moser and Witmer 2000). In some cases, the intensive grazing can also reduce vegetative competition with tree saplings. In addition to reducing the food available to rodents, the livestock grazing may also compact the soil and disrupt burrow systems (Witmer and Fantinato 2003).

Field flooding and burning are two other methods of habitat management that are sometimes used to reduce rodent populations and the habitat carrying capacity for rodents. These approaches are mainly used in agriculture areas before crop planting (in the case of flooding) or after crop harvest (in the case of burning). They are also used more so in developing countries where other methods are not readily available or affordable. 


\section{Encourage Natural Predation}

The habitat needs, and especially cover requirements, for most rodents are critical because of the constant threat of predation, both day and night (see Ylönen et al. 2002). Knowing this, farm, ranch, and natural resource managers have tried to increase predator densities and reduce available cover as ways to reduce rodent populations and damage. Unfortunately, prey populations usually drive predator populations, not the other way around. Artificial perches and nest boxes have been constructed to attract hawks and owls near croplands, orchards, and grasslands. Especially where natural perches were limited, these structures were used by raptors that preyed upon rodents and other animals such as rabbits (Ojwang and Oguge 2003; Witmer et al. 2008a); while the methods seemed to slow population growth and colony expansion, they did not prevent it completely. In contrast, there is other evidence that suggests the rodent population or rodent damage is not substantially reduced as a result of predator attraction (e.g., Howard et al. 1985; Pelz 2003; Sheffield et al. 2001).

\section{Fertility Control}

Fertility control is often considered an attractive alternative to lethal control of rodents. There have been small-scale trials with various chemical compounds and some of these materials (e.g., diazacon and nicarbazin) have shown promise (Miller et al. 1998; Fagerstone 2002). There are, however, many difficulties to overcome before any of these materials become available on the commercial market (Fagerstone et al. 2010; Tyndale-Biscoe and Hinds 2007; McLeod et al., 2007), including the need for an effective remote delivery system and the need to get a national, state, or /provincial registration that would allow the use of compounds in the field, especially given that the effects of such compounds would probably not be species-specific (Fagerstone 2002). Using viruses as a vector for delivering speciesspecific sterility proteins has proven effective under laboratory conditions, but the level of natural transmission to unaffected animals has been insufficient to proceed with field trials (Redwood et al. 2007; Campbell et al. 2015). Currently, GonaCon is registered in the US for the control of over abundant white-tailed deer (Odocoileus virginianus) and feral horses (Equus caballus) and feral burros (Equus asinus) (Fagerstone et al. 2010). Another product, OvoControl, is registered for overabundant Canada goose (Branta canadensis) control (Fagerstone et al. 2010). However, no products have been registered in the U.S. for rodent fertility control, although several materials have shown promise including GonaCon and diazacon (Mayle et al. 2013; Nash et al. 2007; Yoder and Miller 2011). Several other compounds and approaches have shown promise for fertility control of rodents (German 1985; Seeley and Reynolds 1989; Jacob et al. 2006; Zhao et al. 2007). An oral delivery system is important-versus the need for injection-if a fertility control agent is to be effective and efficient method for rodent control. Ongoing research with a 
palatable liquid formulation (ContraPest) has provided promising results (Dyer and Mayer 2014; Pyzyna et al. 2014; Witmer et al. 2017) and was recently registered by the USEPA for use with Norway and black rats. It should be noted that damage may still occur once animals are sterilized, but presumably, the population will be slower to increase in density and less likely to expand into unoccupied areas. Because many species of rodents are territorial, it is also presumed that the immigration of fertile individuals will not occur much until the sterile animals begin to die off. There has also been some preliminary investigation of the ability of altered light cycles (e.g. artificial light at night in fields) to influence vole reproduction (Haim et al. 2004), although it is too soon to know if this will be an effective method of rodent population reduction.

\section{Disease Agents}

Another theoretical way to reduce rodent populations is through disease agents or parasites. This approach has not yet had successes like those achieved during control for pest insect and plant populations. A major concern of using vertebrate biocides is that the agent may affect non-target species, including humans and livestock (Painter et al. 2004). This has been the case with the use of Salmonella spp. to control rats. A blood protozoan parasite, Trypanosoma evansi (Singla et al. 2003) and a liver nematode, Capillaria hepatica (=Callodium hepaticum) (Barker et al. 1991) have shown some potential for their ability to safely control rats and mice, however, the effect at the population level has not been sufficient to provide effective control. In Thailand, the protozoan, Sarcocystis singaporensis, is being investigated as a potential biocide (Boonsong et al. 1999; Khoprasert et al. 2008). A major problem is the maintenance of the disease agent or parasite in the environment after the target pest population has been greatly reduced. While there have been substantial successes with invasive rabbit population control in Australia with the use of a myxoma virus and a rabbit calicivirus (Pech 2000; Angulo and Bárcena 2007), there has been limited success with biological control of other mammal pest populations (see reviews by Leirs and Singleton 2006; Baker et al. 2007).

\section{Research Needs and Conclusions}

Additional research is needed to improve existing methods and to develop new methods for rodent detection, control, and damage reduction. Such efforts should include both lethal and nonlethal means of resolving rodent damage situations (Witmer et al. 1995; Witmer and Singleton 2012). Emphasis should include, but not be limited to, detection methods, new rodenticides, effective repellents, and 
barrier development and improvement; biological control; fertility control; and habitat manipulation (Blackie et al. 2014; Campbell et al. 2015; Eason et al. 2010). It is difficult to prioritize these research areas because progress is needed in all areas (Howard 1988). Some promising new areas of rodent research include RNA interference as a species-specific toxicant, and transgenic rodents (Campbell et al. 2015). Researchers also need to identify effective commercially-available rodenticide formulations for specific locations, regions, or islands as Pitt et al. (2011) have done for rats and mice in Hawaii and Witmer and Moulton (2014) have done for the central mainland US. This is especially important for the successful eradication of invasive rodents on islands (e.g., Howald et al. 2007; Witmer et al. 2007b; Witmer and Pitt 2012). Another important research need is the evaluation of the effectiveness of combinations of techniques, given that some combinations could potentially be much more effective in the reduction of damage and may be more acceptable to the public (e.g., Baldwin et al. 2013). For example, combining sanitation and barriers (i.e., limiting rodent access) may lessen the amount and frequency of use of traps and toxicants.

Rodents will continue to pose challenges to land and resource managers, commodity producers, and homeowners (e.g., Capizzi et al. 2014; Witmer and Singleton 2012). Many tools are available to reduce rodent populations and associated damage. They should be used in a designed IPM program. Rodenticides will continue to be an important tool to control rodents and their damage, but care must be exercised in their use. It is probably safe to assume that much of the public will continue to be leery of toxicant use. Hence, public education will be important to ensure continued availability of rodenticides. Continued technology development and transfer are essential to improve the effectiveness and safety of rodenticides and other methods used to control or eradicate invasive rodents as well as native rodents causing damage.

Additionally, seabird populations, sea turtle populations and other island resources warrant protection from invasive rodents. The recovery of fauna and flora on uninhabited islands after a successful rodent eradication is particularly notable (Witmer et al. 2007a, Witmer and Pitt 2012). The significant impacts of introduced rodents on native flora and fauna have been repeatedly demonstrated. Invasive rodents are very adaptable, can exploit a wide array of resources as food and cover, and can increase reproduction very quickly when and where abundant resources exist (Macdonald et al. 1999). While invasive rodents and commensal rodents will continue to pose challenges to land and resource managers, they can be controlled or even eradicated with a well-planned and adequately-supported effort using rodenticides and other tools. With proper planning, non-target losses will be minimal and these populations, along with other island and mainland resources, will often recover quickly after the invasive and commensal rodents have been removed (Croll et al. 2016; Le Corre et al. 2015; Newton et al. 2016). 


\section{References}

Ahmed MS, Fiedler LA (2002) A comparison of four rodent control methods in Philippine experimental rice fields. Int Biodeter Biodegr 49:125-132

Angel A, Wanless RM, Cooper J (2009) Review of impacts of the introduced house mouse on islands in the Southern Ocean: are mice equivalent to rats? Biol Invasions 11:1743-1754

Angulo E, Bárcena J (2007) Towards a unique and transmissible vaccine against myxomatosis and rabbit haemorrhagic disease for rabbit populations. Wildl Res 34:567-577

Baker RO, Bodman GR, Timm RM (1994) Rodent proof construction and exclusion methods. In: Hygnstrom SE, Timm RM, Larson GE (eds) Prevention and control of wildlife damage. Cooperative Extension Division, University of Nebraska, Lincoln, pp B-137-B-150

Baker SE, Singleton GR, Smith RH (2007) The nature of the beast: using biological processes in vertebrate Pest management. In: Macdonald DW, Service K (eds) Key topics in conservation biology. Blackwell Publishing, London, UK, pp 173-185

Baldwin R, Salmon T, Schmidt R, Timm R (2013) Wildlife pests of California agriculture: regional variability and subsequent impacts on management. Crop Prot 46:29-37

Baldwin R, Salmon T, Schmidt R, Timm R (2014) Perceived damage and areas of needed research for wildlife pests of California agriculture. Integr Zool 9:265-279

Baldwin RA, Meinerz R, Witmer GW (2016) Cholecalciferol plus diphacinone baits for vole control: a novel approach to a historic problem. J Pest Sci 89:129-135

Baldwin R, Meinerz R, Witmer G (2017) Novel and current rodenticides for pocket gophers Thomomys spp.: what works? Pest Manag Sci. 73:118-122

Barker SC, Singleton GR, Spratt DM (1991) Can the Nematode Capillaria Hepatica regulate abundance in wild house mice? Results of enclosure experiments in Southeastern Australia. Parasitology 103:439-449

Blackie HM, MacKay JWB, Allen WJ, Smith DHV, Barrett B, Whyte BI, Murphy EC, Ross J, Shapiro L, Ogilvie S, Sam S, MacMorran D, Inder S, Eason CT (2014) Innovative developments for long-term mammalian pest control. Pest Manag Sci 70:345-351

Boonsong P, Hongnark S, Suasa-ard K, Khoprasert Y, Promkerd P, Hamarit G, Nookarn P, Jakel T (1999) Rodent management in Thailand. In: Singleton GR, Hinds LA, Leirs H, Zhang Z (eds) Ecologically-based management of rodent pests. Australian Centre for International Agricultural Research, Canberra, pp 338-357

Brown PR, Davies MJ, Singleton GR, Croft JD (2004) Can farm-management practices reduce the impact of house mouse populations on crops in an irrigated farming system? Wildl Res 31:597-604

Buckle A, Eason C (2015) Control methods: chemical. In: Buckle A, Smith R (eds) Rodent pests and their control, 2nd edn. CAB International, Wallingford, pp 123-154

Buckle AP, Smith RH (2015) Rodent pests and their control, 2nd edn. CAB International, Wallingford, $422 \mathrm{pp}$

Campbell KJ, Beek J, Eason CT, Glen AS, Godwin J, Gould F, Holmes ND, Howald GR, Madden FM, Ponder JB, Threadgill DW, Wegmann AS, Baxter GS (2015) The next generation of rodent eradications: innovative technologies and tools to improve species specificity and increase their feasibility on islands. Biol Conserv 185:47-58

Capizzi D, Bertolini S, Mortelliti A (2014) Rating the rat: global patterns and research priorities in impacts and management of rodent pests. Mammal Rev 44:148-162

Caughley J, Bomford M, Parker B, Sinclair R, Griffiths J, Kelley D (1998) Managing vertebrate pests: rodents. Bureau of Resource Sciences and Grains Research and Development Corporation, Canberra, $130 \mathrm{pp}$

Corrigan RM (1998) The efficacy of gluetraps against wild populations of house mice, Mus musculus. In: Baker RO, AC Crabb (eds) Proceedings of the 18th vertebrate pest conference, 20th Vertebrate Pest Conference, CostaMesa, 2-5 Mar 1998, pp 268-275

Corrigan RM (2001) Rodent control: a practical guide for Pest management professionals. GIE Media, Cleveland, $355 \mathrm{pp}$ 
Cowan P, Brown S (2015) Review of rodent monitoring and control methods as alternatives to glueboard traps. MPI technical/information paper no: 2015/15. Wellington, NZ

Cowan P, Brown S, Forrester G, Booth L, Crowell M (2015) Bird-repellent effects on bait efficacy for control of invasive mammal pests. Pest Manag Sci 71:1075-1081

Croll D, Newton K, McKown M et al (2016) Passive recovery of an island bird community after rodent eradication. Biol Invasions 18:703-715

Dyer CA, Mayer LP (2014) Sprague Dawley female rat consumption of a liquid bait cantaining vinylcyclohexene diepoxide and triptolide leads to subfertility. In: Timm RM, O'Brien JM (eds) Proceedings of the 26th vertebrate pest conference, 26th Vertebrate Pest Conference, Waikoloa, 3-6 Mar 2014, pp 386-390

Eason CT, Fagerstone KA, Eisemann JD, Humphrys S, O'Hare JR, Lapidge SJ (2010) A review of existing and potential new world and Australasian vertebrate pesticides with a rationale for linking use patterns to registration requirements. Int J Pest Manag 56(2):109-125

Eisemann J, Swift C, Dunlevy P, Pitt W, Witmer G (2010) Regulatory and policy issues around non-target mortality and environmental fate of rodenticides. In: Timm RM, Fegerstone K (eds) Proceedings of the 24th vertebrate pest conference, 24th Vertebrate Pest Conference, Sacramento, 22-25 Feb 2010, pp 208-212

Fagerstone KA (2002) Professional use of pesticides in wildlife management - an overview of professional wildlife damage management. In: Timm RM, Schmidt RH (eds) Proceedings of the 20th vertebrate pest conference, 20th Vertebrate Pest Conference, Reno, 4-7 Mar 2002, pp 253-260

Fagerstone KA, Miller LA, Killian G, Yoder CA (2010) Review of issues concerning the use of reproductive inhibitors, with particular emphasis on resolving human-wildlife conflicts in North America. Integr Zool 1:15-30

Fortier G, Bard N, Jansen M, Clay K (2000) Effects of tall fescue endophyte infection and population density on growth and reproduction in prairie voles. J Wildl Manag 64:122-128

German A (1985) Contact effect of diethylstilbestrol (DES) on the suppression of reproduction in the Levant vole, (Microtus guentheri). Acta Zool Fenn 173:179-180

Giusti GA, Whisson DA, Gorenzel WP (1996) Rodents and cover crops - a review. In: Timm RM, Crabb AC (eds) Proceedings of the 17th vertebrate pest conference, 17th Vertebrate Pest Conference, Rohnert Park, 5-7 Mar 1996, pp 59-61

Haim A, Shanas U, Zisapel N, Gilboa A (2004) Rodent pest control:use of photoperiod manipulations as a tool. In: Feare C, Cowan D (eds) Advances in vertebrate pest management III. Finlander Verlag, Furth, pp 29-38

Hansen SC, Stolter C, Jacob J (2015) The smell to repel: the effect of odors on the feeding behavior of female rodents. Crop Prot 78:270-276

Hansen SC, Stolter C, Jacob J (2016) Effect of plant secondary metabolites on feeding behavior of microtine and arvicoline rodent species. J Pest Sci 89(4):955-963

Howard WE (1988) Areas of further research. In: Prakash I (ed) Rodent pest management. CRC Press, Boca Raton, pp 451-458

Howard WE, Marsh RE, Corbett CW (1985) Raptor perches: their influence on crop protection. Acta Zool Fenn 173:191-192

Howald G, Donlan CJ, Galvan JP, Russell JC, Parkes J, Samaniego A, Wang Y, Veitch D, Genovesi P, Pascal M, Sbaunders A, Tershy B (2007) Invasive rodent eradication on islands. Conservation Biology 21(5):1258-1268.

Hunter JE (1991) Grazing and pocket gopher abundance in a California annual grassland. Southwest Nat 36:117-118

Hygnstrom SE, Timm RM, Larson GE (1994) Prevention and control of wildlife damage. University of Nebraska Cooperative Extension, Lincoln

International Association of Fish and Wildlife Agencies (IAFWA) (2006) Best management practices for trapping in the United States. IAFWA Furbearer Resources Technical Work Group, Washington, DC 
International Organization for Standardization (IOS) (1999a) Animal (mammal) traps: part 4: methods for testing killing trap systems used on land or underwater. IOS, Geneva

International Organization for Standardization (IOS) (1999b) Animal (mammal) traps: part 5: methods for testing restraining trap systems used on land or underwater. IOS, Geneva

Jackson M, Hartley S, Linklater W (2015) Better food-based baits and lures for invasive rats Rattus spp. and the brushtail possum Trichosurus vulpecula: a bioassay on wild, free-ranging animals. J Pest Sci 89(2):479-488

Jacob J, Brown PR, Aplin KP, Singleton GR (2002) Ecologically-based management of pest rodents in rice-based agro-ecosystems in Southeast Asia. In: Timm RM, Schmidt RH (eds) Proceedings of the 20th vertebrate pest conference, 20th Vertebrate Pest Conference, Reno 4-7 Mar 2002, pp 67-74

Jacob J, Rahmini J, Sudarmaji J (2006) The impact of imposed female sterility on field populations of ricefield rats (Rattus argentiventer). Agric Ecosyst Environ 115:281-284

Jahn GC, Solieng M, Cox PG, Nel C (1999) Farmer participatory research on rat management in Cambodia. In: Singleton GR, Hinds LA, Leirs H, Zhang Z (eds) Ecologically-based management of rodent pests. Australian Centre for International Agricultural Research, Canberra, pp 358-371

Jojola SM, Witmer GW, Burke PW (2009) Evaluation of attractants to improve trapping success of nutria on Louisiana coastal marsh. J Wildl Manag 73(8):1414-1419

Khoprasert Y, Promkerd P, Ginting S, Jakel T (2008) Combination of biological rodent control using Sarcocystis singaporensis with anticoagulant rodenticides. In: Burton EN, Williams PV (eds) Crop protection research advances. Nova Science Publishers, New York, pp 145-161

Le Corre M, Danckwerts D, Ringler D et al (2015) Seabird recovery and vegetation dynamics after Norway rateradication at Tromelin Island, western Indian Ocean. Biol Conserv 185:85-94

Leirs H, Singleton G (2006) Parasites and pest population management. In: Morand S, Krasnov B, Poulin R (eds) Mammals and macroparasites: from evolutionary ecology to management. Springer-Verlag, Tokyo, pp 565-591

Lossa G, Soulsbury C, Harris S (2007) Mammal trapping: a review of animal welfare standards of killing and restraining traps. Anim Welf 16:335-352

Macdonald DW, Mathews F, Berdoy M (1999) The behaviour and ecology of Rattus norvegicus: from opportunism to kamikaze tendencies. In: Singleton GR, Hinds LA, Leirs H, Zhang Z (eds) Ecologically-based management of rodent pests. Australian Centre for International Agricultural Research, Canberra, pp 49-80

Marsh RE (1988) Rodent problems on the North American continent. In: Prakash I (ed) Rodent pest management. CRC Press, Inc., Boca Raton, Florida, pp 1-11

Marsh RE, Koehler AE, Salmon TP (1990) Exclusionary methods and materials to protect plants from pest mammals - A review. In: Davis LR, Marsh RE (eds) Proceedings of the 14th vertebrate pest conference, 14th Vertebrate Pest Conference, Sacramento, 6-8 Mar 1990, pp 174-180

Mason JR (1998) Mammal repellents: options and considerations for development. In: Baker RO, Crabb AC (eds) Proceedings of the 18th vertebrate pest conference, 18th Vertebrate Pest Conference, Costa Mesa, 2-5 Mar 1998, pp 325-329

Massawe AW, Leirs H, Rwamugira WP, Makundi RH (2003) Effect of land preparation methods on spatial distribution of rodents in crop fields. In: Singleton GR, Hinds LA, Krebs CJ, Spratt DM (eds) Rats, mice and people: rodent biology and management. Australian Centre for International Agricultural Research, Canberra, pp 229-232

Mayle B, Ferryman M, Peace A, Yoder C, Miller L, Cowan D (2013) The use of DiazaCon to limit fertility by reducing serum cholesterol in female grey squirrels, Sciurus carolinensis. Pest Manag Sci 69:414-424

McLeod SR, Saunders G, Twigg LE, Arthur AD, Ramsey D, Hinds LA (2007) Prospects for the future: is there a role for virally vectored immunocontraception in vertebrate pest management? Wildl Res 34:555-566

Miller L, Johns B, Elias D (1998) Immunocontraception as a wildlife management tool: some perspectives. Wildl Soc Bull 26:237-243 
Morgan DR, Arrow J, Smith MP (2013) Combining aspirin with cholecalciferol (vitamin $\mathrm{D}_{3}$ ) - a potential new tool for controlling possum populations. PLoS One 8(8):e70683

Moser BW, Witmer GW (2000) The effects of elk and cattle foraging on the vegetation, birds, and small mammals of the Bridge Creek wildlife area, Oregon. Int Biodeterior Biodegrad 45:151-157

Murphy E, Sjoberg T, Barun A, Aylett P, MacMorran D, Eason C (2014) Development of re-setting toxin delivery devices and long-life lures for rats. In: Timm RM, O'Brien JM (eds) Proceedings of the 26th vertebrate pest conference, 26th Vertebrate Pest Conference, Waikoloa, 3-6 Mar 2014, pp 396-399

Nash P, Furcolow CA, Bynum KS, Yoder CA, Miller LA, Johnston JJ (2007) 20, 25-Diazacholesterol as an oral contraceptive for black-tailed prairie dog population management. Hum Wildl Confl 1(1):60-67

Newton K, McKown M, Wolf C et al (2016) Response of native species ten years after the rat eradication on Anacapa Island, California. J Fish Wildl Manag 7(1):72-85

Ngowo V, Lodal J, Mulungu LS, Makundi RH, Massawe AW, Leirs H (2003) Evaluation of thiram and cinnamamide as potential repellents against maize-seed depredation by the Multimammate rat, (Mastomys natalensis), in Tanzania. In: Singleton GR, Hinds LA, Krebs CJ, Spratt DM (eds) Rats, mice and people: rodent biology and management. Australian Centre for International Agricultural Research, Canberra, pp 260-261

Nogeire T, Lawler J, Schumaker N, Cypher B, Phhillips S (2015) Land use as a driver of patterns of rodenticide exposure in modeled kit fox populations. PLoS One. doi:10.1371/journal. pone. 0133351

Nowak R (1999) Walker's mammals of the world, vol II, 6th edn. Johns Hopkins University Press, Baltimore, $1936 \mathrm{pp}$

Oguge N, Ndung'u D, Okemo P (1997) Effects of Neem Plant (Azadirachta Indica Juss, meliaceae) products on maize grain consumption by three common rodent pests in Kenya. In: Leirs $\mathrm{H}$, Schockaert E (eds) Rodent biology and integrated pest management in Africa: Belgian journal of zoology. From the proceedings of the international workshop held in Morogoro (vol. 127, suppl. 1), the International Workshop held in Morogoro, Tanzania, Africa, 21-25 Oct 1996, pp 129-135

Ojwang DO, Oguge NO (2003) Testing a biological control program for rodent management in a maize cropping system in Kenya. In: Singleton GR, Hinds LA, Krebs CJ, Spratt DM (eds) Rats, mice and people: rodent biology and management. Australian Centre for International Agricultural Research, Canberra, pp 251-253

Painter JA, Mølbak K, Sonne-Hansen J, Barrett T, Wells JG, Tauxe RV (2004) Salmonella-based rodenticides and public health. Emerg Infect Dis 10(6):985-987

Pech RP (2000). Biological control of vertebrate pests. In: Salmon TP, Crabb AC (eds) Proceedings of the 19th vertebrate pest conference, 19th Vertebrate Pest Conference, San Diego, 6-9 Mar 2000, pp 206-211

Pelton MR, Fribourg HA, Laundre JW, Reynolds TW (1991) Preliminary assessment of small wild mammal populations in tall fescue habitats. Tenn Farm Home Sci 160:68-71

Pelz H (2003) Current approaches towards environmentally benign prevention of vole damage in Europe. In: Singleton GR, Hinds LA, Krebs CJ, Spratt DM (eds) Rats, mice and people: rodent biology and management. Australian Centre for International Agricultural Research, Canberra, pp 233-237

Pelz H (2007) Spread of resistance to anticoagulant rodenticides in Germany. Int J Pest Manag 53(4):299-302

Peters DH, Schumacher K, Schumacher RJ, Baigent DW (2014) Goodnature automatic traps for vertebrate pest control: field trials using new kill traps targeting animal pests in New Zealand. In: Timm RM, O'Brien JM (eds) Proceedings of the 26th vertebrate pest conference, 26th Vertebrate Pest Conference, Waikoloa, 3-6 Mar 2014, pp 405-410

Pitt W, Driscoll L, Sugihara R (2011) Efficacy of rodenticide baits for the control of three invasive rodent species in Hawaii. Arch Environ Contam Toxicol 60:533-542 
Pitt W, Berensten A, Shiels A, Volker S, Eisemann J, Wegmann A, Howald G (2015) Non-target species mortality and the measurement of brodifacoum rodenticide residues after a rat (Rattus rattus) eradication on Palmyra atoll, tropical Pacific. Biol Conserv 185:36-46

Prakash I (1988) Rodent pest management. CRC Press, Boca Raton, 480 pp

Proulx G (1997) A northern pocketgopher (Thomomys talpoides) border control strategy: promising approach. Crop Prot 16:279-284

Proulx G (1999) Mammal trapping. Alpha Wildlife Research \& Management, Sherwood Park, $231 \mathrm{pp}$

Proulx G (2014) On the misuse of pesticides to control northern pocket gophers and Richardson's ground squirrels in agriculture and the pressing need for sustainable solutions. In: Holroyd GL, Trefry AJ, Crockett B (eds) Proceedings of the 10th prairie conservation and endangered species conference, Engaging People in Conservation, 10th Prairie Conservation and Endangered Species Conference, Red Deer, 19-22 Feb 2013, pp 134-157

Pyzyna B, Cunningham L, Calloway E, Dyer C, Mayer L, Cowan D (2014) Liquid fertility management bait uptake by urban rats within New York City subway refuse rooms. In: Timm RM, O'Brien JM (eds) Proceedings of the 26th vertebrate pest conference, 26th Vertebrate Pest Conference, Waikoloa, 3-6 Mar 2014, pp 375-379

Rattner B, Horak K, Lazarus R, Eisenreich K, Meteyer C, Volker S, Campton C, Eisemann J, Johnston J (2012) Assessment of toxicity and potential risk of the anticoagulant rodenticide diphacinone using eastern screech-owls (Megascops asio). Ecotoxicology 21:832-846

Rattner BA, Horak KE, Lazarus RS, Goldade DA, Johnston J (2014a) Toxicokinetics and coagulopathy threshold of the rodenticide diphacinone in eastern scheech-owls (Megascops asio). Environ Toxicol Chem 33(1):74-81

Rattner BA, Lazarus RS, Elliott JE, Shore RF, van den Brink N (2014b) Adverse outcome pathway and risks of anticoagulant rodenticides to predatory wildlife. Environ Sci Technol 48:8422-8445

Redwood AJ, Smith LM, Lloyd ML, Hinds LA, Hardy CM, Shellam GR (2007) Prospects for virally vectored immunocontraception in the control of wild house mice (Mus domesticus). Wildl Res 34:530-539

Salatti C, Woolhouse A, Vandenbergh J (1995) The use of odors to induce avoidance behavior in pine voles. In: King M (ed) Proceedings of the 6th eastern wildlife damage control conference, the 6th Eastern Wildlife Damage Control Conference, Ashville, 3-6 Oct 1993, pp 149-151

Salmon TP, Marsh R, Stroud D (1987) Influence of burrow destruction on recolonization of California ground squirrels. Wildl Soc Bull 15:564-568

Seeley RR, Reynolds TD (1989) Effect of indomethacin-treated wheat on a wild population of montane voles. Great Basin Nat 49:556-561

Sheffield LM, Crait JR, Edge WD, Wang G (2001) Response of American kestrels and gray-tailed voles to vegetation height and supplemental perches. Can J Zool 79(3):380-385

Shumake SA, Kolz AL, Reidinger RF, Fall MW (1979) Evaluation of nonlethal electrical barriers for crop protection against rodent damage. In: Beck JR (ed) Vertebrate pest control and management materials, proceedings from the second symposium sponsored by American Society for Testing and Materials. American Society for Testing and Materials, Philadelphia, pp 29-38

Singla N, Parshad VR, Singla LD (2003) Potential of (Trypanosoma evansi) as a biocide of rodent pests. In: Singleton GR, Hinds LA, Krebs CJ, Spratt DM (eds) Rats, mice and people: rodent biology and management, ACIAR Monograph No. 96, Canberra, pp 43-46

Singleton GR, Sudarmaji, Suriapermana S (1998) An experimental field study to evaluate a trapbarrier system and fumigation for controlling the rice rat in rice crops in West Java. Crop Prot 17:55-64

Singleton GR, Leirs H, Hinds LA, Zhang Z (1999) Ecologically-based management of rodent pests - re-evaluating our approach to an old problem. In: Singleton GR, Hinds LA, Leirs $\mathrm{H}$, Zhang Z (eds) Ecologically-based management of rodent pests. Australian Centre for International Agricultural Research, Canberra, pp 17-29 
Singleton GR, Hinds LA, Krebs CJ, Spratt DM (2003) Rats, mice and people: rodent biology and management. Clarus Design, Canberra, $564 \mathrm{pp}$

Singleton GR, Sudarmaji, Jacob J, Krebs CJ (2005) Integrated management to reduce rodent damage to lowland rice crops in Indonesia. Agric Ecosyst Environ 107:75-82

Singleton GR, Brown PR, Jacob J, Aplin KP, Sdarmaji (2007) Unwanted and unintended effects of culling: a case for ecologically-based rodent management. Integr Zool 2:247-259

Singleton GR, Belmain S, Brown P, Hardy B (eds) (2010) Rodent outbreaks: ecology and impacts. International Rice Institute, Los Banos, 289 pp

Sullivan TP, Klenner W (1993) Influences of diversionalry food on red squirrel populations and damage to crop trees in young lodgepole pine forests. Ecol Appl 3:708-718

Sullivan TP, Crump DR, Sullivan DS (1988) Use of predator odors as repellents to reduce feeding damage by herbivores IV: northern pocket gophers. J Chem Ecol 14:379-389

Suriapermana S (1998) An experimental field study to evaluate a trap-barrier system and fumigation for controlling the rice rat in rice crops in West Java. Crop Prot 17:55-64

Timm R (1994) Active ingredients. In: Hygnstrom SE, Timm RM, Larson GE (eds) Prevention and control of wildlife damage, Cooperative Extension Division, University of Nebraska, Lincoln, pp G-23-G-61

Timm RM (2003) Devices for vertebrate pest control: are they of value? In Fagerstone KA, Witmer GW (eds) Proceedings of the 10th wildlife damage management conference, The 10th Wildlife Damage Management Conference, Hot Springs, 6-9 Apr 2003, pp 152-161

Tyndale-Biscoe H, Hinds LA (2007) Introduction - virally vectored immunocontraception in Australia. Wildl Res 34(7):507-510

Warburton B, Gormley A (2015) Optimising the application of multiple-capture traps for invasive species management using spatial simulation. PLoS One. doi:10.1371/journal.pone.0120373

Werner SJ, Tupper SK, Pettit SE, Carlson JC, Linz GM (2011) Anthraquinone repellent to reduce take of non-target birds from zinc phosphide rodenticide applications. Appl Anim Behav Sci 135:146-153

Witmer GW (2005) Wildlife population monitoring: some practical considerations. Wildl Res 32:259-263

Witmer G (2007) The ecology of vertebrate pests and integrated pest management (IMP). In: Kogan M, Jepson P (eds) Perspectives in ecological theory and integrated pest management. Cambridge University Press, Cambridge, UK, pp 393-410

Witmer G (2011) Rodent population management at Kansas City International Airport. Hum Wildl Interact 5(2):269-275

Witmer G, Borrowman D (2012) Effects of turf rolling and soil aeration on rodent populations. In Timm RM (ed) Proceedings of the 25th vertebrate pest conference, 25th Vertebrate Pest Conference, Monterey, 5-8 Mar 2012, pp 338-340

Witmer G, Eisemann JD (2007) Rodenticide use in rodent management in the United States: an overview. In: Nolte DL, Arjo WM, Stalman D (eds) Proceedings of the 12th wildlife damage management conference, 12th Wildlife Damage Management Conference, Corpus Christi, 9-12 Apr 2007, pp 114-118

Witmer G, Fantinato J (2003) Management of rodents at airports. In: Fagerstone KA, Witmer GW (eds) Proceedings of the 10th wildlife damage management conference, 10th Wildlife Damage Management Conference, Hot Springs, 6-9 Apr 2003, pp 350-358

Witmer GW, Moulton RS (2014) Improving invasive house mice control and eradication strategies via more effective rodenticides. In: Timm RM, O'Brien JM (eds) Proceedings of the 26th vertebrate pest conference, 26th Vertebrate Pest Conference, Waikoloa, 3-6 Mar 2014, pp 67-72

Witmer G, Pitt W (2012) Invasive rodents in the United States: ecology, impacts, and management. In: Blanco J, Fernandes A (eds) Invasive species: threats, ecological impact and control methods. Nova Science Publishers, New York, pp 47-75

Witmer G, Singleton G (2012) Sustained agriculture: the need to manage rodent damage. In: Triunveri A, Scalise D (eds) Rodents: habitat, pathology and environmental impact. Nova Science Publishers, New York, pp 145-182 
Witmer GW, VerCauteren KC (2001) Understanding vole problems in direct seeding - strategies for management. In: Veseth R (ed) Proceedings of the northwest direct seed cropping systems conference, Northwest Direct Seed Conference, Spokane, 17-19 Jan 2001, pp 104-110

Witmer GW, Fall MW, Fiedler LA (1995) Rodent control, research, and technology transfer. In: Bissonette J, Krausman P (eds) Integrating people and wildlife for a sustainable future, from the proceedings of the first international wildlife management congress. The Wildlife Society, Bethesda, pp 693-697

Witmer G, Hakim A, Moser B (2001) Investigations of methods to reduce damage by voles. Proc East Wildl Damage Control Conf 9:357-365

Witmer GW, Boyd F, Hillis-Starr Z (2007a) The successful eradication of introduced roof rats (Rattus rattus) from Buck Island using diphacinone, followed by an irruption of house mice (Mus musculus). Wildl Res 34:108-115

Witmer G, Eisemann JD, Howald G (2007b) The use of rodenticides for conservation efforts. In: Nolte DL, Arjo WM, Stalman D (eds) Proceedings of the 12th wildlife damage management conference, 12th Wildlife Damage Management Conference, Corpus Christi, 9-12 Apr 2007, pp 160-167

Witmer G, Sayler R, Huggins D, Capelli J (2007c) Ecology and management of rodents in no-till agriculture in Washington, USA. Integr Zool 2:154-164

Witmer G, Pipas M, Burke P, Rouse D, Dees D, Manci K (2008a) Raptor use of artificial perches at natural areas, City of Fort Collins, Colorado. Prairie Nat 40:37-42

Witmer G, Gionfriddo J, Pipas M (2008b) Evaluation of physical barriers to prevent prairie dog colony expansion. Hum Wildl Confl 2(2):206-211

Witmer GW, Snow NP, Burke PW (2010) Potential attractants for detecting and removing invading Gambian giant pouched rats (Cricetomys gambianus). Pest Manag Sci 66:412-416

Witmer G, Horak K, Moulton R, Baldwin RA (2013) New rodenticides: an update on recent research trials. In: Armstrong JB, Gallagher GR (eds) Proceedings of the 15th wildlife damage management conference, 15th Wildlife Damage Management Conference, Clemson, South Carolina, 25-27 Mar 2013, pp 79-85

Witmer GW, Moulton RS, Baldwin RA (2014a) An efficacy test of cholecalciferol plus diphacinone rodenticide baits for California voles (Microtus californicus) to replace ineffective chlorophacinone baits. Int J Pest Manag 60(4):275-278

Witmer GW, Snow NP, Moulton RS (2014b) Responses by wild house mice (Mus musculus) to various stimuli in a novel environment. Appl Anim Behav Sci 159:99-106

Witmer G, Moulton R (2016) Design of a low-maintenance, long-term bait station for rodent control. Proc Wildl Damage Manage Conf 16:21-25

Witmer G, Raymond-Whish S, Moulton R, Pyzyna B, Calloway E, Dyer C, Mayer L, Hoyer P (2017) Compromised fertility in free feeding wild-caught Norway rats (Rattus norvegicus) with a liquid bait containing 4-vinylcyclohexene diepoxide and triptolide. J Zoo Wildl Med 48(1):80-90

Ylönen H, Jacob J, Davies M, Singleton GR (2002) Predation risk and habitat selection of Australian house mice (Mus domesticus) during an incipient plague: desperate behaviour due to food depletion. Oikos 99:284-289

Yoder C, Miller L (2011) Effect of GonaCon vaccine on black-tailed prairie dogs: immune response and health effects. Vaccine 29:233-239

Zhao M, Liu M, Li D, Wan X, Hinds LA, Wang Y, Zhang Z (2007) Anti-fertility effect of levonorgestrel and quinestrol in Brandt's voles (Lasiopodomys brandtii). Integr Zool 2:260-268 